Journal of Contemporary Research in Business, Economics and Finance

ISSN: 2641-0265

Vol. 3, No. 2, pp. 48-59.

2021

Publisher: Learning Gate

DOI: 10.33094/26410265.2021.32.48.59

(C) 2021 by the authors; licensee Learning Gate

\title{
The Influence of Geographical Conditions, Area and Information System on Economic Development: Mediating Impacts of International Relations
}

\author{
Andrey Loskutov \\ University of Duisburg-Essen, Germany. \\ Email:Andrey.Los@uni-due.de \\ Olivier Pierre \\ University in Saint Petersburg, Russia.
}

Received: 8 February 2021; Revised: 10 June 202 1; Accepted: 29 June 202 1; Published: 9 August 2021

\begin{abstract}
The goal attached to the ongoing research is to explore the influence of geographical conditions, geographical area and information system on the economic development in Russia. The aim that is also attached with the current article is to examine the mediating impact of international relations among the nexus of geographical conditions, geographical area, information system and economic development in Russia. The study and questionnaires have followed the quantitative method of collecting data were used for this purpose. The economist and geographical planner are the respondents while smart-PLS were used to analyze the data by means of checking the reliability, validity and testing of hypotheses. The results show that geographical conditions, geographical area and information system have a positive association with economic development in Russia. The outcomes also exposed that international relations positively mediates among the links of geographical conditions, geographical area, information system and economic development in Russia. These outcomes are providing the guidelines to the regulators that they should increase their focus on the geographical conditions, area and information system factors that could enhance economic development in the country.
\end{abstract}

Keywords: Geographical conditions, Geographical area, Information system, International relations, Economic development.

\section{Introduction}

The issues of economic development are prominent with the aspects of numerous factors which are essential in the geographies. It is the need of every country to develop the economy not only for local lives of people but also for the development of strong relationships with other countries. Globally, the development of economies considered as primary goal and objective for the better contribution toward its people. Various stages belong to the development of economies where the takeoffs are everyone's need for its country. Different theories also developed for the developing economies of countries that are poor. Sociotechnical issues discussed with transitions and bio-economies, including some special issues related to the geographical conditions (Calvert, Kedron, Baka, \& Birch, 2017). Although to bring positive implementation, the natural disasters countered as the dominant and immeasurable endorsing impact on the country growth.

A strong process is defined by the countries, which helps countries to introduce and implement various measures to strengthen the economic and political conditions where the social context of people emphasized. It further did for the establishment of sustainable lives of people through innovative means. Some eminent proclamations operated internationally also endorse the dominant impact, but the 
geography is also important. The study analyzed the proximity of geography with the financial centers to analyze the disclosure of corporate social responsibility while emphasizing the economies of various countries (Zamir \& Saeed, 2020). Many countries are prevalent on the geographical conditions because most of the income generations belong to the specific operations. The countries national conditions also operated by the conditions of geography, which through various devastating elements, develop numerous instances. Specifically, if the single country dominated to the instance of elaborating geographical conditions, various operations also belong to the entertainment of the economy. Studies implemented geography as an important factor inserts an essential role in developing the economy as well as the lives of people.

The evolution of distributions belongs to the areas where the resources are arranged with geographic conditions while inducing the economies of less developed countries (Sun et al., 2019). Most of the sectors are dominant in belongings to the sustainable development of agriculture as well as a digital one. Studies discussed plenty of monitoring elements which are essential for economic development. Through the monitoring and critic views, the geography maintained by the vast implementation of procedures. Fundamental elements prevail in the geographical conditions that insert various influences toward the economy of any country. Some smaller areas are also focused on geographical considerations to analyze the activities performed under the economic spectrum to elaborate enterprises of businesses (Charman, Petersen, Piper, Liedeman, \& Legg, 2017). The natural resources of any country play a vital role in the economic development of any country. There is a direct relationship between economic growth and geographical development. Russia is one of those countries which have multiple natural resources due to its vast geographical territories. The more the country has natural resources, the more it changes to shift its economy from developing to the developed economy. Russian exports by 2030 are expected $73 \mathrm{bcm}$ export to Asia, $155 \mathrm{BCM}$ exports to Europe and $47 \mathrm{BCM}$ exports to CIS.

Most importantly, the geographical area countered as important in establishing the various opportunities to the economy and grounds of the economy linked with various factors which could help the financial and socio-economic conditions. Therefore, the arrangements toward geographical area are eminently dominant for grabbing the various incidents of economic development, to the distribution of economic activities, the scope of geography results in the allocation of various distribution measures. The information system implemented for the geographic conditions with the effective methods of multicriteria where the feasible locations are traced (Villacreses, Gaona, Martínez-Gómez, \& Jijón, 2017). The geographical area is useful in the factors that influence the theories that are prevalent in the realization of local and international aspects. Studies contribute to the regions that are scoped as necessary for the establishment of a positive economic world - the realization of economic conditions which elaborated through various factors important in the regional context.

The implementing information system of geography with the effectiveness of developing countries inducing strategies and available resources (Rosas-Flores, Zenón-Olvera, \& Gálvez, 2019). Numerous activities performed with the help of various developing measures introduced internationally. The international, as well as local means of economy, are developed with the introduction of global and international conditions which are eminent for local development. Economies of the countries are interlinked globally by facilitating through plenty of norms. The scope of internationalization in various companies has enhanced with the performance innovations which inserts a significant role, including international collaborations (Hurtado-Torres, Aragón-Correa, \& Ortiz-de-Mandojana, 2018). International relations countered as an essential element which helps to enhance and up bring the economies of developing countries that are affected by the geographical context. Therefore, broader scopes of international relationships that could help to establish alliances to generate plenty of benefits while most of the international relations built based on a geographical context that enables various trade opportunities globally.

Plenty of markets are striving with the choices of foreign performances where the relationships termed as dominant among the economic growth and geographical aspects (Hollender, Zapkau, \& 
Schwens, 2017). Usually, the relations are not influential on the sovereignty of countries, but it helps to secure the border situations of countries. The distribution of geographical areas to the improvement of trading helps to generate economic opportunities. It usually plays a mediating role among numerous countries snot only to tight the security measures but also insert a vital role for economic development. Numerous alliances of neighbor are known in studies striving positively by strengthening mutual benefits. The elements of socio-economic developments are the primary focus of many countries by emphasizing the aspects of specific geographies where plenty of projects are established (Ivanter, 2018). Geographical information is also essential for the striving economies that are prevalent for the international markets. Countries use various measures to analyze the information system of geography for essential use of developing the economy through various aspects.

The importance of locations is wide interpretations of useable and non-useable lands which co8uld positively insert prominent impacts of the economy. The useful information's of geography help countries to employ resources to the lands which could be cultivated or used for other allocations. Investments from foreign countries also dominate with the effects of geographical conditions where the various emissions ascertained by the developing countries (Sarkodie \& Strezov, 2009). It dominates as statistical interpretations which help to foresee the positive conclusions which develop the economy. Economies have certainly used as an essential mean for the measurement of the economy from internal and external aspects. The use of geographical information system helps the economies of various countries developed from the aspects of starting fresh projects. The developed countries termed as important for the establishment of various strategies which returns the best accomplishing elements which influence economies. The share of natural resources GDP rent (oil, gas, coal, mineral and forestry rent) in the Russian economy is more than halved from 44.5 per cent to 18.7 per cent between 2000 and 2017 (See Figure-1). The real oil and gas share was 15.5\%. The major portion of national resources in Russia is oil and gas. Both the factors are considered as key elements of any country economy.

\section{Share of natural resources rents in GDP*}

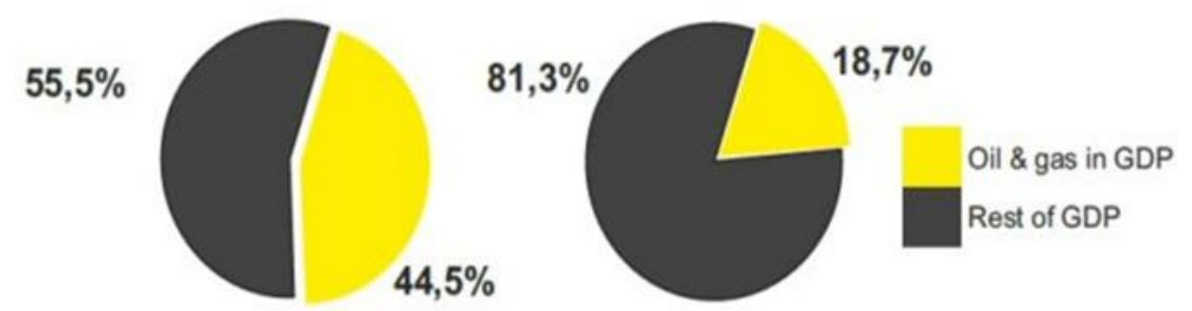

Figure-1.

Share of Russian natural resources in GDP.

The natural resources of any country decide the future direction of the country economy. The countries that are rich in terms of natural resources enjoy a stable and prosperous economy. The natural resources of any country strongly depend upon the geographical location and conditions of the country. Those countries who remind well aware of their natural resources ultimately results in a stable economy as the natural resources contribute soundly in the economy of the country. The more the economy of the country will get support from the exports, the more it will spend on the prosperity of its people. So the natural resources support the economy, and in turn, the economy spends on the geographical development of the country. 


\section{Literature Review}

Although economic development linked with the numerous striving measures, the development of various skills and infrastructure in people and societies is a significant contribution toward economic growth. The planning is discussed with the effects of geographical generations while modelling the economic establishments where the disparities of geography are consistent in some economies (Sahu \& Pani, 2020). Many countries moved to artificial environments, which if results adversely could not harm the actual aspects of the economy. Human settlements tend as essential aspects of sustaining the economic context of the countries, which could help the ease of interpretations of economic scope in the international struggle of development. The gigs of economies are related to the geographical areas where the global markets are operated internationally through digital labour in many countries (D'Archivio et al., 2019).

Most importantly, the people of specific geographical areas are fulfilling the needs from different modes countered as a developing aspect of the economy. In the far east oceans, the geographical information system had worked efficiently for the adjacent needs of waters and the economic development of specific countries striving for economic development (Villacreses et al., 2017). Literature contributed various essential elements that are related to the geographical area and are helpful for economic development. Some disparities prevail among many countries with the scope of immigrants; therefore, the relationships dominate with important role among geographies (Ferrari, Rosnati, Canzi, Ballerini, \& Ranieri, 2017). Tourism, agriculture and various important sectors indulged with the geographical development that immensely helps to develop financial means of economy. With the development of infrastructure as well as the improvement in technology, the mode of collecting information is easier nowadays. Many challenges prevail in economic development; therefore, various stages required to entertain the policies established to attain the targets (Liobikiené \& Butkus, 2018). The induction of satellites and various technological elements and the geographical information system has widely analyzed as an influencing element for the economy. The development of an economy linked with the geographical context is essential for any country.

The cycles and perspectives are essential in analyzing the essence of geographical conditions which are eminent in literature. Some disasters are, importantly, measurable elements which endorse various impacts on the economy, through the induction of thematic scope, monitoring of adverse conditions dominantly covered by the use of a variety of variables. The study analyzed the role of foreign ownership, emphasizing the locations of other countries affiliated with the developing economies and performance of countries (Konwar et al., 2017). While reviewing past conditions, it is also useful to discover and foresee the upcoming events forming disaster situations that could disrupt the economic factors and geographical conditions linked with the natural environment, which recognizes the usage of soil and land. The study argued the weakness of specializations while focusing on the economic resilience of techniques with geographical conditions (De Roest, Ferrari, \& Knickel, 2018). Although, various disasters are essential which could have had influenced the economies in past decades. The features that are related to the conditions are most related to the environmental factors of physical elements and natural elements. It is important to enumerate the hidden aspects which continuously disrupts the operational capabilities of economic development. Most of the countries retain economic growth by the instance of developing various factors while the importance of doing it could be great using geographical factors.

The gain of the economy is essential for the lives of people to introduce the importance of all other elements. The context of studies that are prevalent for the development of economies is gradually increasing with the induction of geographical areas. Studies analyzed the agenda of communities which focus the geographical areas for the business purposes where the dominance is among the economic sectors (Potts, Niewiadomski, \& Prager, 2019). Economies of countries are important for the sustainability of the lives of people and the establishment of local projects. Through, encompassing various activities, the elements widely stated in literature are important while numerous projects enhanced after the establishment of various norms compulsory to introduce the new faces of financial 
contributions. Geographical differentiation is also an essential element where the structures reformed with Russian economies, specifically from pacific Russia (Baklanov \& Moshkov, 2017). Cultural and social aspects are important in the geographical areas that open new opportunities in the context of projects that could enhance economic levels. Different countries elect areas of geography to contribute various financial measures to its people and country whereas; the importance contributes to developing economy. The uses of geographical areas are significantly allocated with its importance to induce positive scenarios. Private sectors considered as important in contributing positive growth toward its public to generate various opportunities that could be dominant in contribution to the local economy.

Data collected from various sources which help in the compilation of factors that are useful for the economic conditions. The economy developed through various elements; therefore, the use of exact information system for the development of the economy could be intact with the positive influences of useful information. Studies used some systems of information for the integration of analyzing geographical conditions in some dynamics of site landfills while considering the data sources (Aksoy \& San, 2019). The geographical information system linked with the hardware, software, and many other factors contribute to compiling the facts about the economy. Studies used the information system in various sectors which dominantly analyzes the proclaiming factors essential for the economies. The study aimed to analyze the role of technology in some geographical areas to assess the responsiveness and effectiveness for improving the capacities of local organizations (Liu, Hung, Tse, \& Saggau, 2020). Countries are widely using information system for the geographical norms to help the sustainable environment for the institutions as well as for the economies. The effects of the geographical information system are primarily important for the assertion of plenty of financial incorporations that help in the development of economies from various aspects. The literature discussed geographical conditions, areas and information system important elements inserting positive for the economic development. At the same time, some countries considered as important influenced by the geographical changes retained globally.

International relations are essential in structuring the economies by opening various projects that help to increase employment levels and for moving towards developing economies. Studies used a variety of factors prevailing in international relations that strengthen the geographical aspects to overcome disaster conditions. Various implications prevail whether short term or long term but the impacts are clear with exploration and exploitation that dominates on the growth of economies and geographies (Sousa, Li, \& He, 2020). The allocation of geographical areas significantly influences the economies of the world, whether endorsing positives or negative, but the eminent mean tends to be developing economy. Studies inserted broader aspects of geographical factors and economic development which are positively mediated by the role of international relations. Some sort of geographical conditions is essential in the sustainable lives of people who indulged in the agriculture sector. The commercial sectors considered in retaining the aspects of geography because most of the economic development based on international relations as well as geographical prospects (Ma, Cai, Cai, \& Dong, 2019). Whereas the geographical conditions through a wide range of factors expressly and impliedly countered as input in the development of the economy. Studies mentioned geographical conditions and the essential part which helps in building and demolishing the economy. Economic development could be done through various means where the ease of doing business is the primary aspect; therefore, it is the responsibility of countries to provide effective modes of sustainability.

It is the uniqueness of relationships that exist between the cultures ad natures of various countries. These countries are bound to perform acts with the geographical relationships that are important for economic development; therefore, the dominant mode of international relations establishes positive role to tackle the adverse conditions. The ambidexterity of teams from the individuals inserts some important role with the international relations collaborating among the economies and geographical structures (Salas-Vallina, Moreno-Luzón, \& Gil-Marqués, 2020). Global chains of introducing foreign ambassadors are eminent steps that develop positive gaps to introduce geographical benefits to countries for economies. The cooperation with the effects of geographical aspects toward economies 
helps to overcome devastating elements that are harmful to the economies of countries. Countries usually face the impacts of natural resources; therefore, the importance of geographies are dominant in literature with the economic development while focusing some specific countries (Danish, Mahmood, \& Zhang, 2019). The high population rate also belongs to economic development, which dominantly possessed with the effectiveness of commodities. The dominant economic development must be the sufficiency of low unemployment poverty and numerous factors.

The global relations are not only reliable for the generation of economic opportunities but also helps to the introduction of developing strong links with neighbors, the middle role of international relations seen in studies that increase the importance of geography for the economic development. The countries adopt the various legislative measure to secure the geographical issues that are mutually important. Various diversifications of companies are eminent with international relations and dominate with some effects over the industries as well as economic development (Jang, Kwon, Ahn, Lee, \& Park, 2019). Literature inserts economic development as the primary mean for which geography induces a positive role. Many factors of the geography are influential toward economic sustainability with positive roles of variables. It further discussed important because many countries rely on the geographies to contribute sufficient outcome toward the economies. Studies enumerated the factors of economic development associates with the urbanization where social changes are frequent due to the transitional economies (Fan et al., 2019). As many countries indulged in tourism and evaluation of natural resources; therefore, the development of an economy is more related to the geographical information system. Usually, economic development is pertinent with the belongings of various factors that used for the structural and reform purposes. Based on the above literature, the present study has developed the following hypotheses.

H1: Geographical conditions significantly influence the economic development of Russia.

H2: Geographical area significantly impacts the economic development of Russia.

H3: Geographical information system positively influences economic development of Russia.

H4: International relations significantly and positively mediates among the relationship between geographical conditions and economic development of Russia.

H5: International relations significantly and positively mediates among the relationship between geographical area and economic development of Russia.

H6: International relations significantly and positively mediates among the relationship between geographical information system and economic development of Russia.

\section{Research Methods}

The goal of the research is to explore the influence of geographical conditions, geographical area and information system on the economic development in Russia along with the examination of the mediating impact of international relations among the nexus of geographical conditions, geographical area, information system and economic development in Russia. The study and questionnaires have followed the quantitative method of collecting data were used for this purpose. The economist and geographical planner are the respondents that have been selected by using purposive sampling. A total of 410 surveys were distributed to the respondents by using mail along with a personal visit. After fifteen days of distribution, only 240 surveys were returned that is about 58.54 per cent response rate. In addition, smart-PLS was used to analyze the data by means of checking the reliability, validity and testing of hypotheses. This tool was selected due to the complex framework, and the purpose of the research is the testing of hypotheses (Sarstedt \& Cheah, 2019).

The variables that have been taken include economic development (ED) that is taken as a predictive variable that has four items. In addition, international relations (IR) is used as a mediator in the research that also has four items. Moreover, three independent variables have been taken named as geographical conditions (GC) that has five items, geographical area (GA) that has six items and geographical information system (GIS) that has three items. These variables, along with relationships, are shown in Figure 2. 


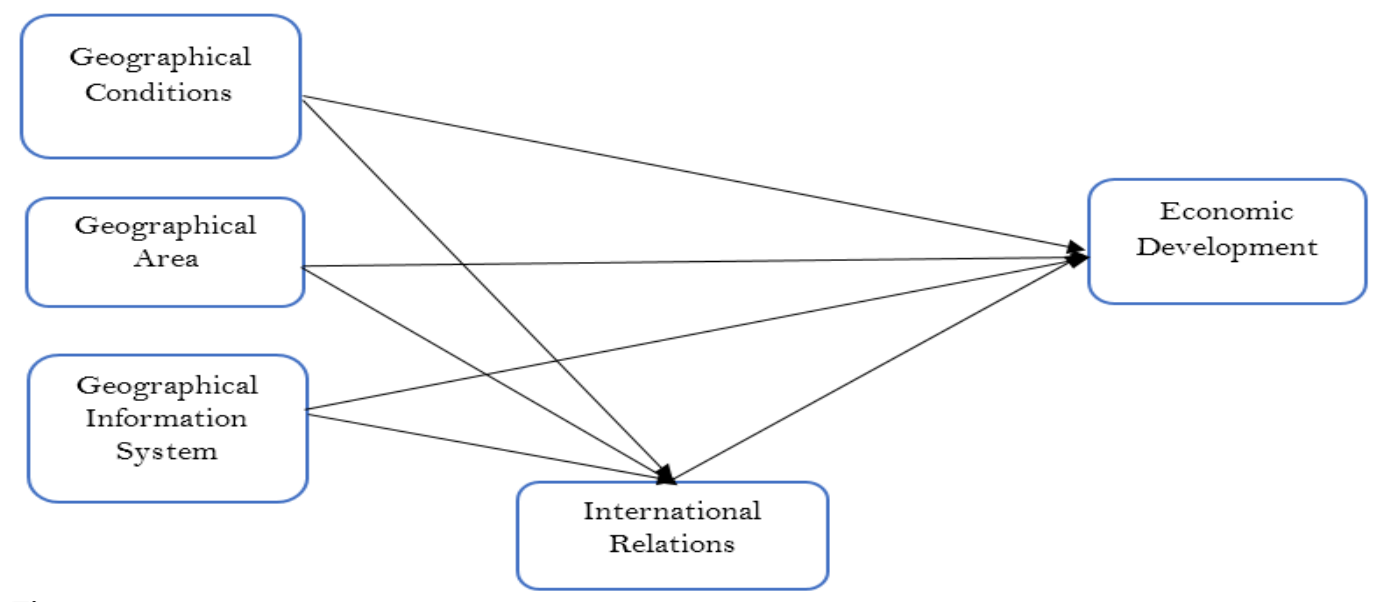

Figure-2.

Theoretical Framework.

\section{Findings}

The outcomes exposed the correlation among items in the first section of the results that is known as convergent validity. The values of composite reliability $(\mathrm{CR})$ and Alpha are bigger than 0.70, along with values of loadings and AVE that are larger than 0.50. These are the indications of valid convergent validity and the extensive correlation between items. These statistics are shown in Table 1.

Table-1.

Convergent validity.

\begin{tabular}{|c|c|c|c|c|c|}
\hline Constructs & Items & Loadings & Alpha & CR & AVE \\
\hline \multirow[t]{3}{*}{ Economic Development } & ED1 & 0.774 & 0.827 & 0.898 & 0.747 \\
\hline & ED3 & 0.913 & & & \\
\hline & $\mathrm{ED} 4$ & 0.900 & & & \\
\hline \multirow[t]{6}{*}{ Geographical Area } & GA1 & 0.836 & 0.869 & 0.900 & 0.601 \\
\hline & GA2 & 0.724 & & & \\
\hline & GA3 & 0.726 & & & \\
\hline & GA4 & 0.787 & & & \\
\hline & GA5 & 0.767 & & & \\
\hline & GA6 & 0.805 & & & \\
\hline \multirow[t]{5}{*}{ Geographical Condition } & GC1 & 0.785 & 0.802 & 0.865 & 0.565 \\
\hline & $\mathrm{GC}_{2}$ & 0.839 & & & \\
\hline & GC3 & 0.823 & & & \\
\hline & $\mathrm{GC} 4$ & 0.624 & & & \\
\hline & GC5 & 0.662 & & & \\
\hline \multirow[t]{3}{*}{ Geographical Information System } & GIS1 & 0.872 & 0.798 & 0.883 & 0.716 \\
\hline & GIS2 & 0.899 & & & \\
\hline & GIS3 & 0.761 & & & \\
\hline \multirow[t]{4}{*}{ International Relation } & IR 1 & 0.792 & 0.773 & 0.803 & 0.511 \\
\hline & $\mathrm{IR} 2$ & 0.519 & & & \\
\hline & IR3 & 0.744 & & & \\
\hline & IR4 & 0.77 & & & \\
\hline
\end{tabular}

The outcomes also exposed the correlation among variables in the second section of the results that is known as discriminant validity. The values of Heterotrait Monotrait (HTMT) ratio that is lower than 
0.90 are the indications of valid discriminant validity and lack of correlation between variables. These statistics are shown in Table 2.

Table-2.

Discriminant validity.

\begin{tabular}{c|c|c|c|c|c}
\hline & ED & GA & GC & GIS & IR \\
\hline ED & & & & & \\
\hline GA & 0.791 & & & & \\
\hline GC & 0.742 & 0.679 & & & \\
\hline GIS & 0.731 & 0.729 & 0.658 & & \\
\hline IR & 0.700 & 0.684 & 0.607 & 0.726 & \\
\hline
\end{tabular}

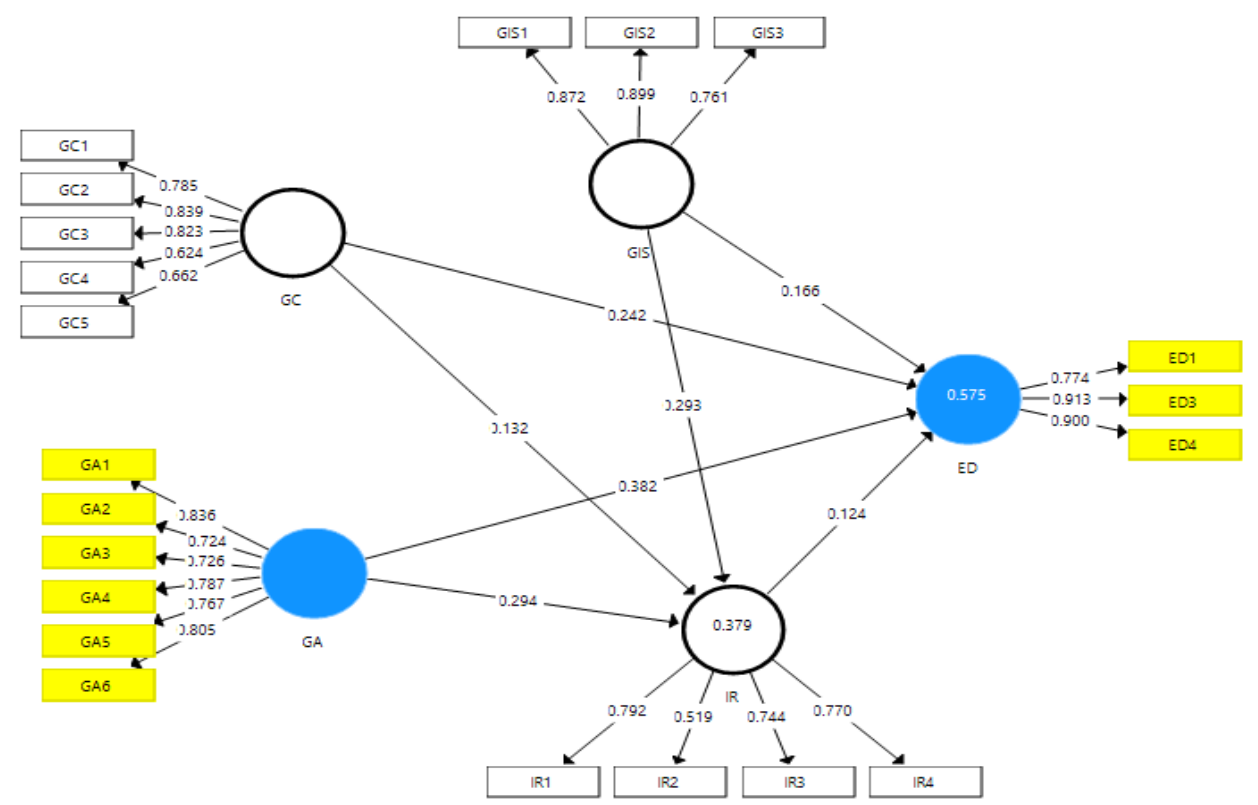

Figure-3.

Measurement model assessment.

Table-3.

Path analysis.

\begin{tabular}{l|c|c|c|c|c|c}
\hline Relationships & Beta & S.D. & t-statistics & p-values & L.L. & U.L. \\
\hline GA -> ED & 0.382 & 0.040 & 9.467 & 0.000 & 0.300 & 0.468 \\
\hline GA -> IR & 0.294 & 0.040 & 7.325 & 0.000 & 0.228 & 0.359 \\
\hline GC -> ED & 0.242 & 0.034 & 7.146 & 0.000 & 0.194 & 0.303 \\
\hline GC -> IR & 0.132 & 0.042 & 3.111 & 0.002 & 0.035 & 0.203 \\
\hline GIS -> ED & 0.166 & 0.033 & 5.024 & 0.000 & 0.107 & 0.231 \\
\hline GIS -> IR & 0.293 & 0.041 & 7.167 & 0.000 & 0.219 & 0.360 \\
\hline IR -> ED & 0.124 & 0.032 & 3.838 & 0.000 & 0.063 & 0.187 \\
\hline GA -> IR -> ED & 0.036 & 0.011 & 3.281 & 0.001 & 0.017 & 0.059 \\
\hline GC -> IR -> ED & 0.016 & 0.007 & 2.466 & 0.015 & 0.006 & 0.029 \\
\hline GIS -> IR -> ED & 0.036 & 0.011 & 3.353 & 0.001 & 0.017 & 0.057 \\
\hline
\end{tabular}

The outcomes also show in Figure 3 the path analyses that is related to the hypotheses testing the figures show that geographical conditions, geographical area and information system have a positive 
association with economic development in Russia and accept $\mathrm{H} 1, \mathrm{H} 2$ and $\mathrm{H}$ 3.In addition, the outcomes also exposed that international relations positively mediates among the links of geographical conditions, geographical area, information system and economic development in Russia and accept H4, H5 and H6. These links are highlighted in Table 3.

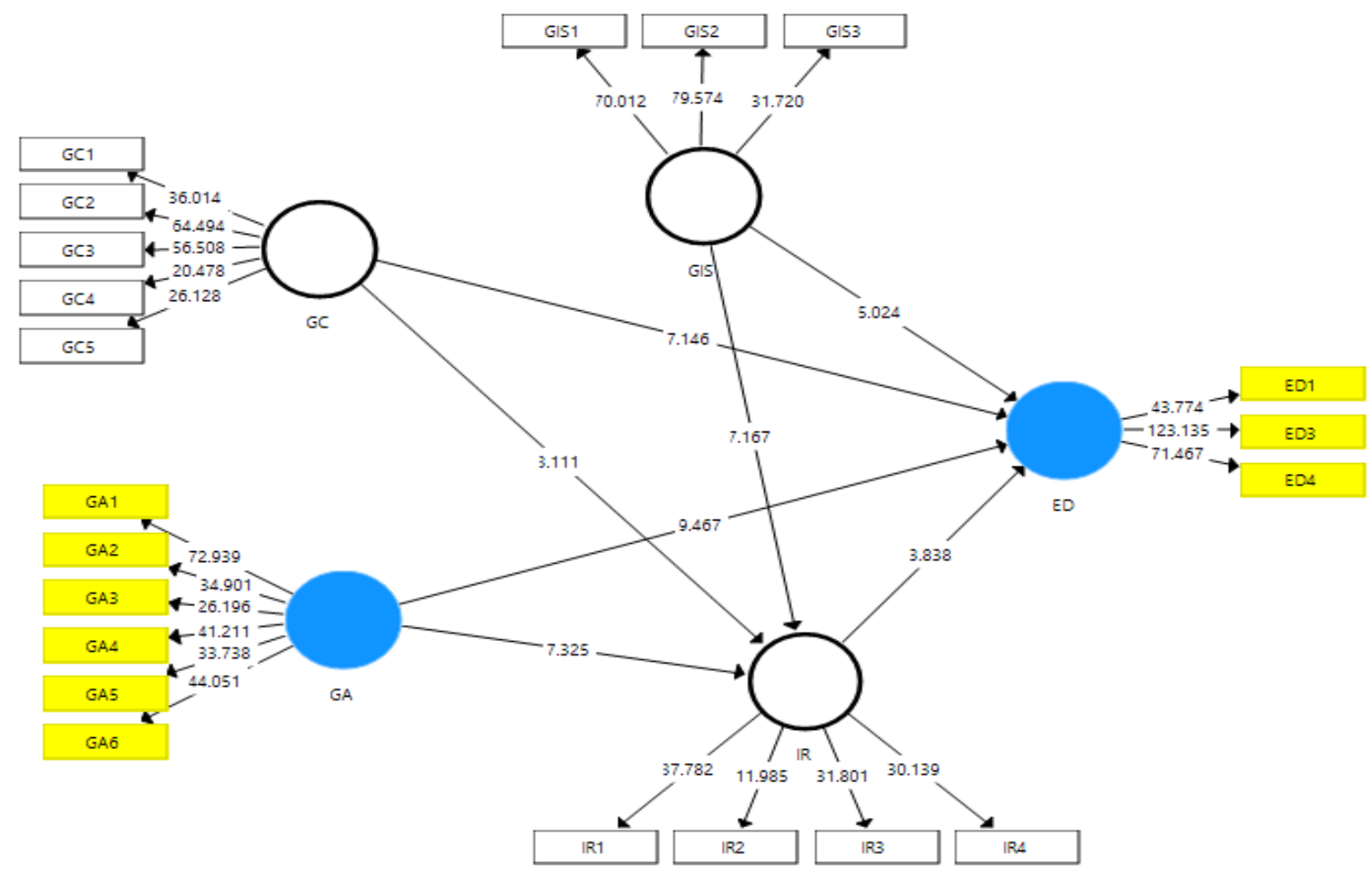

Figure-4.

Structural model assessment.

\section{Discussion and Implications}

The results of the current study have revealed that geographical conditions are in a positive association with economic development. These results are in positive link with past studies of Scholvin (2016) which show that the favorable geographical conditions enhance the rate of economic development. The results have also indicated that the geographical area is positively associated with economic development. These results agree with the results of past studies of Hadjimichalis (2011), according to which the increase in the length of the geographical area improves the rate of economic development. Moreover, the results have indicated that there is a positive association between the quality and quantity of geographical information and the rate of economic development. These results are in line with past studies of Sánchez-Lozano, Teruel-Solano, Soto-Elvira, and García-Cascales (2013), which reveal that the high quality of geographical information increases the rate of economic development. Furthermore, the results have indicated that international relations are an important mediator between the nature of geographical conditions and the rate of economic development. These results match with the studies of Beuermann, McKelvey, and Vakis (2012) according to which economic conditions affect international relations which further affect economic development. The results have also revealed that international relations are an appropriate mediator between geographical area and economic development. These results match with the results of previous studies of Spolaore and Wacziarg (2013), which reveal that the length of the geographical area affects international relations which further accelerates the rate of economic development. Besides, the results of the study have 
revealed that international relations play a mediating role between geographical information and economic development. These results are in accordance with the past studies of Moraczewska (2010), which reveal that the quality of geographical information affects international relations which results in a high rate of economic development.

This piece of literature carries out both the theoretical and empirical implications. The study makes theoretical implications as it makes much more contribution to the literature on economic growth. The study describes that the geographical conditions, geographical area, and geographical information put positive impacts on the rate of economic development. The study also adds to the literature on economic growth by addressing international relations as a mediator between geographical conditions, geographical area, and geographical information and economic development. This study is providing the guidelines to the regulators that they should increase their focus on the geographical conditions, area and information system factors that could enhance economic development in the country. The study makes empirical implications as it provides a guideline to the government of how to accelerate the rate of economic development with the favorable geographical conditions, the large geographical area, and consistent, comprehensive, and accurate geographical information. It also guides the government on how to accelerate the rate of economic development in the presence of better international relations as a mediator between geographical conditions, geographical area, and geographical information and economic development.

\section{Conclusion and Limitations}

In conclusion, it can be said that there is a positive association between geographical conditions and economic development. The study examines that favorable economic conditions improve the rate of economic development. The study concludes that the geographical area is in a positive relationship with economic development. The greater the length of the geographical area, the higher the rate of economic development. The results reveal that geographical information has a positive association with economic development as the better quality geographical information enhances the rate of economic development. Besides, the study examines that international relations are a suitable mediator between geographical conditions, geographical area, and geographical information, and economic development. Thus, geographical conditions, geographical area, and geographical information help to improve international relations which result in a higher rate of economic development.

The study has several limitations despite the detailed description of the economic development and the three determiners of economic development such as geographical conditions, geographical area, and geographical information. The study addresses only these three variables which affect the rate of economic development while there several other variables affecting the rate of economic development, which should be addressed by future scholars in their investigations. Moreover, the writer of this study has adopted only a single source for the collection of data to advocate his study but future scholars should collect the concerned data by using more than one source. This study has introduced the variable international relations as a mediator between geographical conditions, geographical area, and geographical information, and economic development which the same variable should be used as a moderator in future studies.

\section{References}

Aksoy, E., \& San, B. T. (2019). Geographical information systems (GIS) and multi-criteria decision analysis (MCDA) integration for sustainable landfill site selection considering dynamic data source. Bulletin of Engineering Geology and the Environment, 78(2), 779-791.Available at: 10.1007/s10064-017-1135-z.

Baklanov, P. Y., \& Moshkov, A. (2017). Geographical differentiation of territorial structures of the economy in Pacific Russia. Geography and Natural Resources, 38(1), 1-11.Available at: 10.1134/S1875372817010012.

Beuermann, D. W., McKelvey, C., \& Vakis, R. (2012). Mobile phones and economic development in rural Peru. The Journal of Development Studies, 48(11), 1617-1628.Available at: https://doi.org/10.1080/00220388.2012.709615.

Calvert, K. E., Kedron, P., Baka, J., \& Birch, K. (2017). Geographical perspectives on sociotechnical transitions and emerging bio-economies: Introduction to a special issue. Technology Analysis $\Xi^{2}$ Strategic Management, 29(5), 477-485.Available at: 10.1080/09537325.2017.1300643. 
Charman, A. J., Petersen, L. M., Piper, L. E., Liedeman, R., \& Legg, T. (2017). Small area census approach to measure the township informal economy in South Africa. Journal of Mixed Methods Research, 11(1), 36-58.Available at: $10.1177 / 1558689815572024$.

D'Archivio, A. A., Foschi, M., Aloia, R., Maggi, M. A., Rossi, L., \& Ruggieri, F. (2019). Geographical discrimination of red garlic (Allium sativum L.) produced in Italy by means of multivariate statistical analysis of ICP-OES data. Food Chemistry, 275, 333-338.Available at: https://doi.org/10.1016/j.foodchem.2018.09.088.

Danish, B., M. A., Mahmood, N., \& Zhang, J. W. (2019). Effect of natural resources, renewable energy and economic development on $\mathrm{CO} 2$ emissions in BRICS countries. Science of The Total Environment, 678, 632-638.Available at: https://doi.org/10.1016/j.scitotenv.2019.05.028.

De Roest, K., Ferrari, P., \& Knickel, K. (2018). Specialisation and economies of scale or diversification and economies of scope? Assessing different agricultural development pathways. Journal of Rural Studies, 59, 222-231.Available at: https://doi.org/10.1016/j.jrurstud.2017.04.013.

Fan, P., Ouyang, Z., Nguyen, D. D., Nguyen, T. T. H., Park, H., \& Chen, J. (2019). Urbanization, economic development, environmental and social changes in transitional economies: Vietnam after Doimoi. Landscape and Urban Planning, 187, 145-155.Available at: https://doi.org/10.1016/j.landurbplan.2018.10.014.

Ferrari, L., Rosnati, R., Canzi, E., Ballerini, A., \& Ranieri, S. (2017). How international transracial adoptees and immigrants cope with discrimination? The moderating role of ethnic identity in the relation between perceived discrimination and psychological well-being. Journal of Community $\mathcal{E}^{\circ}$ Applied Social Psychology, 27(6), 437-449.Available at: https://doi.org/10.1002/casp.2325.

Hadjimichalis, C. (2011). Uneven geographical development and socio-spatial justice and solidarity: European regions after the 2009 financial crisis. European Urban and Regional Studies, 18(3), 254-274.

Hollender, L., Zapkau, F. B., \& Schwens, C. (2017). SME foreign market entry mode choice and foreign venture performance: The moderating effect of international experience and product adaptation. International Business Review, 26(2), 250263.

Hurtado-Torres, N. E., Aragón-Correa, J. A., \& Ortiz-de-Mandojana, N. (2018). How does R\&D internationalization in multinational firms affect their innovative performance? The moderating role of international collaboration in the energy industry. International Business Review, 27(3), 514-527.Available at: https://doi.org/10.1016/j.ibusrev.2017.10.003.

Ivanter, V. (2018). Prospects of economic development in Russia. Studies on Russian Economic Development, 29(3), 225227.Available at: $10.1134 / \mathrm{S} 107570071803006$.

Jang, Y., Kwon, N., Ahn, Y., Lee, H.-S., \& Park, M. (2019). International diversification and performance of construction companies: Moderating effect of regional, product, and industry diversifications. Journal of Management in Engineering, 35(5), 04019015.Available at: 10.1061/(ASCE)ME.1943-5479.0000713.

Konwar, Z., Papageorgiadis, N., Ahammad, M. F., Tian, Y., McDonald, F., \& Wang, C. (2017). Dynamic marketing capabilities, foreign ownership modes, sub-national locations and the performance of foreign affiliates in developing economies. International Marketing Review, 34(5), 674-704.Available at: 10.1108/IMR-01-2016-0004.

Liobikienè, G., \& Butkus, M. (2018). The challenges and opportunities of climate change policy under different stages of economic development. Science of the Total Environment, 642, 999-1007.Available at: https://doi.org/10.1016/j.scitotenv.2018.06.140.

Liu, H. K., Hung, M. J., Tse, L. H., \& Saggau, D. (2020). Strengthening urban community governance through geographical information systems and participation: An evaluation of my Google Map and service coordination. Australian Journal of Social Issues, 55(2), 182-200.Available at: https://doi.org/10.1002/ajs4.98.

Ma, M., Cai, W., Cai, W., \& Dong, L. (2019). Whether carbon intensity in the commercial building sector decouples from economic development in the service industry? Empirical evidence from the top five urban agglomerations in China. Journal of Cleaner Production, 222, 193-205.Available at: https://doi.org/10.1016/j.jclepro.2019.01.314.

Moraczewska, A. (2010). The changing interpretation of border functions in international relations. Romanian Journal of Political Geography, 10(2), 329-340.

Potts, T., Niewiadomski, P., \& Prager, K. (2019). The green economy research centre - positioning geographical research in Aberdeen to address the challenges of green economy transitions. Scottish Geographical Journal, 135(4), 356370.Available at: 10.1080/14702541.2019.1695907.

Rosas-Flores, J. A., Zenón-Olvera, E., \& Gálvez, D. M. (2019). Potential energy saving in urban and rural households of Mexico with solar photovoltaic systems using geographical information system. Renewable and Sustainable Energy Reviews, 116, 10-12.Available at: https://doi.org/10.1016/j.rser.2019.109412.

Sahu, P. K., \& Pani, A. (2020). Freight generation and geographical effects: Modelling freight needs of establishments in developing economies and analyzing their geographical disparities. Transportation, 47(6), 2873-2902.Available at: 10.1007/s $11116-019-09995-5$.

Salas-Vallina, A., Moreno-Luzón, M. D., \& Gil-Marqués, M. (2020). From individual to team ambidexterity: The moderating role of collaborative behavior and international experience. Knowledge Management Research \& Practice, 1-15.

Sánchez-Lozano, J. M., Teruel-Solano, J., Soto-Elvira, P. L., \& García-Cascales, M. S. (2013). Geographical information systems (GIS) and multi-criteria decision making (MCDM) methods for the evaluation of solar farms locations: Case study in 
south-eastern Spain. Renewable and Sustainable Energy Reviews, 24, 544-556.Available at: https://doi.org/10.1016/j.rser.2013.03.019.

Sarkodie, S. A., \& Strezov, V. (2009). Effect of foreign direct investments, economic development and energy consumption on greenhouse gas emissions in developing countries. Science of The Total Environment, 646, 862-871.Available at: https://doi.org/10.1016/j.scitotenv.2018.07.365.

Sarstedt, M., \& Cheah, J.-H. (2019). Partial least squares structural equation modeling using SmartPLS: A software review. Journal of Marketing Analytics, 7(3), 196-202.

Scholvin, S. (2016). Geographical conditions and political outcomes. Comparative Strategy, 35(4), 274-283.

Sousa, C. M. P., Li, R. Y., \& He, X. (2020). The impact of exploitation and exploration on export sales growth: the moderating role of domestic and international collaborations. Journal of International Marketing, 28(4), 1-20.Available at: $10.1177 / 1069031$ X20963617.

Spolaore, E., \& Wacziarg, R. (2013). How deep are the roots of economic development? Journal of Economic Literature, 51(2), 325-369.

Sun, S., Yin, Y., Wu, P., Wang, Y., Luan, X., \& Li, C. (2019). Geographical evolution of agricultural production in China and its effects on water stress, economy, and the environment: the virtual water perspective. Water Resources Research, 55(5), 4014-4029.Available at: https://doi.org/10.1029/2018WR023379.

Villacreses, G., Gaona, G., Martínez-Gómez, J., \& Jijón, D. J. (2017). Wind farms suitability location using geographical information system (GIS), based on multi-criteria decision making (MCDM) methods: The case of continental ecuador. Renewable Energy, 109, 275-286.Available at: https://doi.org/10.1016/j.renene.2017.03.041.

Zamir, F., \& Saeed, A. (2020). Location matters: Impact of geographical proximity to financial centers on corporate social responsibility (CSR) disclosure in emerging economies. Asia Pacific Journal of Management, 37(1), 263-295.Available at: $10.1007 / \mathrm{s} 10490-018-9619-3$.

Journal of Contemporary Research in Business, Economics and Finance
ISSN: $2641-0265$
Vol. 3, No. 2, pp. $48-59,2021$
DOI: $10.33094 / 26410265.2021 .32 .48 .59$
C) 2021 by the authors; licensee Learning Gate

